\title{
High occurrence of Mycoplasma suis infection in swine herds from non-technified farms in Mossoró, state of Rio Grande do Norte, Northeastern Brazil
}

\author{
Alta ocorrência de infecção por Mycoplasma suis em suínos de criaçôes não tecnificadas de Mossoró, \\ estado do Rio Grande do Norte, Nordeste brasileiro \\ Mariana Aparecida Toledo ${ }^{1}$; Alexandro Iris Leite²; Luiz Ricardo Gonçalves ${ }^{1}$; Keyla Carstens Marques de Sousa'; \\ Renan Bressianini do Amaral ${ }^{1}$; Glaucenyra Cecília Pinheiro da Silva ${ }^{1}$; Rosangela Zacarias Machado ${ }^{1}$; \\ Marcos Rogério André ${ }^{*}$

\begin{abstract}
'Faculdade de Ciências Agrárias e Veterinárias, Universidade Estadual Paulista “Júlio de Mesquita Filho” - UNESP, Jaboticabal, SP, Brasil

${ }^{2}$ Departamento de Ciência Animal, Universidade Federal Rural do Semi-Árido - UFERSA, Mossoró, RN, Brasil
\end{abstract}

Received June 29, 2016

Accepted November 16, 2016

\begin{abstract}
Mycoplasma suis, the etiological agent of swine hemoplasmosis, has been neglected in swine herds around the world. Swine hemoplasmosis is frequently associated with hemolytic anemia, disgalacty, infertility and immunosuppression, and it results in significant economic losses. This study investigates the occurrence of $M$. suis in non-technified swine herds in the northeastern region of Brazil using quantitative PCR (qPCR) based on the 16S rRNA gene. Between March and August 2013, blood samples from 147 swine were collected during slaughter in the city of Mossoró, state of Rio Grande do Norte, northeastern Brazil. One hundred and twelve samples (76.19\%) were positive for $M$. suis by qPCR assays. The range of Cqs and quantification (copies of a M. suis-16S rRNA gene fragment $/ \mu \mathrm{L}$ ) was 20.86-37.89 and $1.64 \times 10^{1}-6.64 \times 10^{7}$, respectively. One can conclude that M. suis infection have high occurrence $(76,19 \%)$ in non-technified swine-rearing systems in Mossoró in the state of Rio Grande do Norte, Brazil.
\end{abstract}

Keywords: Swine hemoplasmosis, swines, hemotropic mycoplasmas, Brazil.

\section{Resumo}

Mycoplasma suis, agente etiológico da hemoplasmose suína, tem sido negligenciado nas criaçôes de suínos ao redor do mundo. A hemoplasmose suína é frequentemente associada à anemia hemolítica, disgalactia, infertilidade e imunossupressão, acarretando em perdas econômicas. O objetivo do presente trabalho foi investigar, por meio da PCR quantitativa (qPCR) baseada no gene rRNA 16S, a ocorrência de M. suis em amostras de sangue de suínos de criaçóes não tecnificadas na cidade de Mossoró, Estado do Rio Grande do Norte. Entre março a agosto de 2013, foram colhidas amostras de sangue de 147 suínos de criaçôes não tecnificadas da referida região. Cento e doze amostras $(76,19 \%)$ amostras mostraram-se positivas na qPCR para M. suis. A média dos Cqs e da quantificação (número de cópias do gene $16 \mathrm{~S}$ rRNA de $M$. suis por microlitro) foi de 20,86 - 37,89 e 1,64 x 10 a 6,64 x 107, respectivamente. Conclui-se que a infecção por $M$. suis apresenta alta ocorrência (76,19\%) em criaçốes de suínos não tecnificadas na cidade de Mossoró, estado do Rio Grande do Norte.

Palavras-chave: Hemoplasmose suína, suínos, micoplasmas hemotrópicos, Brasil.

\section{Introduction}

Knowledge about pathogens that can potentially affect animal welfare and cause economic losses is critical in swine production. Considering that Brazil is the fourth largest producer and exporter of

*Corresponding author: Marcos Rogério André. Laboratório de Imunoparasitologia, Departamento de Patologia Veterinária, Faculdade de Ciências Agrárias e Veterinárias , Universidade Estadual Paulista "Júlio de Mesquita Filho" - UNESP, Via de Acesso Prof. Paulo Donato Castellane, s/n, Zona Rural, CEP 14884-900, Jaboticabal, SP, Brasil. e-mail: marcos_andre@fcav.unesp.br pork meat, constant surveillance of infectious diseases is mandatory in order to maintain high levels of production (BRASIL, 2016). Mycoplasma suis, a bacterium belonging to the Mollicutes Order, is one of the pathogens that affects swine herds and may result in economic losses (HOELZLE, 2008). These bacteria (also known as hemoplasmas) are uncultivable wall-less organisms that parasitize the surface of erythrocytes, leading to structural deformations (HOELZLE, 2008). As a result, hemolytic anemia 
might be noted in the acute phase of the disease (ZACHARY \& SMITH, 1985).

Swine hemoplasmosis has worldwide geographic distribution (MESSICK, 2004) and is frequently associated with severe or moderate chronic hemolytic anemia, disgalacty, infertility and immunosuppression, and it results in economic losses (HOELZLE, 2008).

$M$. suis can be experimentally transmitted by several routes (HENRY, 1979; HENDERSON et al., 1997), and, possibly, by the louse Haematopinus suis (MESSICK, 2004), the stable fly Stomoxys calcitrans, and the mosquito Aedes aegypti (PRULLAGE et al., 1993). Additionally, other routes of transmission of $M$. suis have been speculated since the agent has been detected in urine samples, in water used for drinking, vaginal and nasal secretions, and environmental dust samples (DIETZ et al., 2014).

Although laboratory diagnoses of $M$. suis infections are frequently based on observations of stained-blood smears, this technique lacks sensitivity and specificity. Molecular techniques, mainly qPCR, have been shown to be accurate and quick tests for the diagnosis of $M$. suis, which enable its detection and quantification (GUIMARÁES et al., 2011). Despite the apparent importance of $M$. suis to the swine industry worldwide, reports of this hemoplasma species in swine herds around the world have been rare. The pathogen has only been detected in pigs from China (YUAN et al., 2009; SONG et al., 2014), Germany (RITZMANN et al., 2009; HOELZLE et al., 2010) and Brazil (GUIMARÁES et al., 2007). The zoonotic potential of $M$. suis still needs further investigation since the agent has been molecularly detected in veterinarians and individuals who come into close contact with pig herds in Shanghai, China (YUAN et al., 2009). The goal of this study was to investigate the occurrence of $M$. suis in non-technified swine herds in the northeastern region of Brazil using molecular techniques.

\section{Materials and Methods}

\section{Sampling area, swine blood collection and DNA extraction}

Between March and August 2013, blood samples were collected by jugular vein puncture from 147 pigs, during slaughter. The pigs used in the present study were originally from non-technified swine herds in Mossoró, state of Rio Grande do Norte, Northeastern Brazil. All of the swine farmers have their rearing systems classified as subsistence without technification; the work involved family labor. The sampled herds did not contain infirmaries or quarantine areas, and the animals were not segregated by age. The study was approved by Ethics Committee of Faculdade de Ciências Agrárias e Veterinárias (FCAV - Universidade Estadual Paulista, Jaboticabal), according to protocol number 02/2013 (Process number 23091.003915/2012-42 CEUA/UFERSA).

DNA extraction was performed from whole blood samples using a QIAamp DNA Blood Mini-kit (QIAGEN ${ }^{\circledR}$, Valencia, California, USA), following manufacturer's instructions. The DNA concentration and quality $(260 / 280 \mathrm{~nm}$ ratio) were measured using a Thermo Scientific NanoDrop 2000 Spectrophotometer
(Thermo Fisher Scientific ${ }^{\circledR}$, Wilmington, Delaware, USA). Microtubes containing ultra-pure sterile water were intercalated between each series of twenty blood samples and submitted to DNA extraction. Additionally, in order to avoid contamination, DNA extraction and PCR reactions were performed in separated rooms. The DNA was stored at -20 until the time of cPCR and qPCR testing.

\section{Conventional PCR for the endogenous gene GAPDH}

In order to rule out the presence of inhibitors in extracted DNA samples and thereby avoid false-negative results in qPCR for $M$. suis, all of the DNA samples were submitted to conventional PCR (cPCR) using the primers GAPDH-F (5'-CCTTCATTGACCTCAACTACAT-3') and GAPDH-R (5'-CCAAAGTTGTCATGGATGACC-3'), which flank a fragment of 437 base pairs (bp) of the GAPDH gene (BIRKENHEUER et al., 2003). Polymerase Chain Reaction was performed as previously described by Birkenheuer et al. (2003), with some modifications. The amplification reaction was performed using a final volume of $25 \mu \mathrm{L}$ containing a mixture of $5 \mu \mathrm{L}$ of the DNA sample, $0.2 \mathrm{mM}$ of each desoxynucleotide, $1 \mu \mathrm{M}$ of each primer, $0.75 \mathrm{mM} \mathrm{MgCl}_{2}$, $0.25 \mu \mathrm{L}$ Taq DNA polymerase, 10X PCR buffer and sterile ultra-pure water q.s.p $25 \mu \mathrm{L}$. The cycling conditions were: initial denaturation at $94^{\circ} \mathrm{C}$ for 3 minutes, 35 cycles consisting of denaturation at $94^{\circ} \mathrm{C}$ for 1 minute, annealing at $50^{\circ} \mathrm{C}$ for 2 minutes and extension at $72^{\circ} \mathrm{C}$ for 2 minutes, followed by final extension at $72^{\circ} \mathrm{C}$ for 7 minutes. The amplified products then underwent horizontal agarose gel electrophoresis stained with $1.5 \%$ ethidium bromide $(0.5 \mu \mathrm{L} / \mathrm{mL})$ in TEB ( $\mathrm{pH} 8.0$; Tris base $44.58 \mathrm{M}$; $0.44 \mathrm{M}$ boric acid; $12.49 \mathrm{mM}$ EDTA). The electrophoresis was performed at $90 \mathrm{~V} / 50 \mathrm{~mA}$ for 90 minutes. A molecular weight marker of $100 \mathrm{bp}$ (Thermo Fisher Scientific, Waltham, MA USA) was used to determine the length of amplified products. Amplicons were visualized and analyzed using an ultraviolet transilluminator (Chemi-Doc, Bio-Rad ${ }^{\circledR}$, Hercules, California, USA) coupled to a computational program of image analysis (Image Lab, Bio-Rad, Hercules, California, USA).

\section{Mycoplasma suis qPCR based on the $16 S$ rRNA gene}

DNA samples exhibiting positive results in conventional PCR for the GAPDH gene underwent qPCR for $M$. suis based on 16S rRNA gene, using the primers $\mathrm{F}$ (5'-CCCTGATTGTACTAATTGAATAAG-3') and R (5'- GCGAACACTTGTTAAGCAAG-3') and the hydrolysis probe TaqMan (5'FAM- TGRATACACAYTTCAGMGBNFQ3') (Integrated DNA Technologies ${ }^{\circledR}$, Coralville, Iowa, USA) (GUIMARÃES et al., 2011). The amplification reaction was performed in a Thermal Cycler Model 96 CFX (BioRad ${ }^{\circledR}$, Hercules, California, USA) using a final volume of $10 \mu \mathrm{L}$ containing a mixture of $1 \mu \mathrm{L}$ of DNA sample, $0.2 \mu \mathrm{M}$ of each primer and probe hydrolysis, PCR buffer (IQ Multiplex Mix Power, BioRad ${ }^{\circledR}$, Hercules, California, USA) and sterilized ultrapure water (Nuclease-Free Water, Promega ${ }^{\circledR}$, Madison, Wisconsin, USA) q.s.p. $10 \mu \mathrm{L}$. The thermal conditions were: $95^{\circ} \mathrm{C}$ for 10 minutes followed by 40 cycles at $95^{\circ} \mathrm{C}$ for 15 seconds, $58.5^{\circ} \mathrm{C}$ for 45 seconds and 
$72^{\circ} \mathrm{C}$ for 30 seconds. The qPCR assays followed the Minimum Information for Publication of Quantitative Real-Time PCR Experiments (MIQE) (BUSTIN et al., 2009).

The sensitivity of the qPCR was determined using 10-fold serial dilutions of pIDTSMART plasmids (Integrated DNA Technologies, Coralville, Iowa, USA) encoding $16 S$ rRNA $M$. suis sequence (insert containing $156 \mathrm{bp}$ ). The number of plasmid copies was determined according to the formula $(\mathrm{Xg} / \mu \mathrm{L} / \mathrm{DNA}$ [plasmid size $(\mathrm{bp}) \times 660]) \times 6.022 \times$ plasmid copy $\times 10^{23} / \mu \mathrm{L}$. Plasmids and ultra pure water were used as positive and negative controls, respectively.

The amplification efficiency (E) was calculated from the slope of the standard curve in each run using the following formula: $\mathrm{E}=10^{-1 / \text { slope }}$. To determine the limit of detection and quantification of the TaqMan assay, standard curves were generated by serial dilutions from $10^{7}$ to $10^{0}$ copy numbers of plasmids.

\section{Results}

Out of 147 GAPDH-positive samples, 112 (76.19\%) were positive for $M$. suis. The samples were processed in five different plates with reactions efficiencies (E) of $95.1 \%, 91.9 \%, 93 \%, 98.1 \%$ and $97.5 \%$, respectively (Table 1 ). The range of Cqs and quantification were $20.79-39.82$ and $1.02 \times 10^{1}-5.62 \times 10^{6}$, respectively. Three samples demonstrated inconsistent quantification results and larger variation in the numerical value of Cqs and, consequently, in the number of $M$. suis $16 \mathrm{~S}$ rRNA DNA copies. This finding was most likely due to the Monte Carlo effect (BUSTIN et al., 2009), which represents an inherent limitation of the technique, particularly in samples with low number of $M$. suis DNA. In the present study, the assay sensitivity was 10 copies/ $\mu \mathrm{L}$.

\section{Discussion}

There are few studies reporting the occurrence of $M$. suis in swine herds around the world. The few reports that exist on this subject are from China for conventional PCR (YUAN et al., 2009), Brazil (GUIMARÁES et al., 2007) and Germany (RITZMANN et al., 2009; HOELZLE et al., 2010) for qPCR. The occurrence of $M$. suis noted in this study was similar to that found in China (YUAN et al., 2009) but lower than that found in studies conducted in Germany (RITZMANN et al., 2009; HOELZLE et al., 2010).

The pigs sampled in this study were from non-technified swine herds in northeastern Brazil. These herds lacked nutritional programs, adequate facilities, defined genetics, and standardized management techniques. Similarly, the animals sampled in Shanghai, China (YUAN et al., 2009) were from commercial swine farms that exhibited poor sanitary conditions and provided a favorable environment for the development of arthropod vectors, which may play an important role in $M$. suis transmission between pigs (YUAN et al., 2009). Besides reporting a $M$. suis occurrence rate of $86 \%$ in pigs, 32 out of 65 veterinarians and individuals who worked with the swine herds in Shanghai tested positive for this hemoplasma species.

Yuan et al. (2009) also pointed out that ingesting food contaminated with blood of infected pigs and the reuse of needles were risk factors associated with swine hemoplasmosis in China. Herein, the poor sanitary conditions of swine herds in Mossoró might be quite similar to those found in swine-rearing establishments in Shanghai, China. On the other hand, studies carried out in Germany revealed a lower rate of occurrence of $M$. suis (10.0-13.9\%) (RITZMANN et al., 2009; HOELZLE et al., 2010) than that found in this study (76.19\%). This difference may be mainly due to the technified systems of swine herds in Germany.

According to Song et al. (2014), poor sanitary conditions of swine herds and environmental conditions may favor the maintenance and spread of the pathogen. The garbage that had accumulated might have increased the presence of vectors such as flies and mosquitoes. Therefore, impaired management techniques lead to a lack of environment cleanliness and, consequently, $M$. suis transmission by fomites, such as needles and other materials. The conditions of feeders and drinkers may favor the contamination of food and water with blood, saliva, nasal secretions, dust, and the urine of infected animals, which favors the transmission of the agent (DIETZ et al., 2014).

Our study was conducted in Mossoró, which has an average temperature of $27.4^{\circ} \mathrm{C}$ and a temperature range of $21-36^{\circ} \mathrm{C}$ during a year (MOSSORÓ, 2008), which may help explain the high occurrence rate of $M$. suis. On the other hand, an occurrence rate of $33.1 \%$ and $18.2 \%$ for $M$. suis, assessed via Southern blotting and cPCR, respectively, was found among sows sampled in herds in the state of Santa Catarina, Southern Brazil, where lower temperatures are reported (GUIMARÃES et al., 2007).

Additional studies are necessary to verify the occurrence of $M$. suis in non-technified herds in other Brazilian regions. Furthermore, it will be important to analyze the risk factors associated with infection, positivity and susceptibility according to age groups. Investigations of the real impact of swine hemoplasmosis on swine herd productivity around the world are critically needed. Finally, studies should be conducted in order to estimate the correlation

Table 1. Parameters of $M$. suis-qPCR assays.

\begin{tabular}{cccccc}
\hline Plate & $(\boldsymbol{E})$ & slope & $\mathbf{r}^{2}$ & Cq values & $\begin{array}{c}\text { Quantification of } \boldsymbol{M} \text {. suis-16S rRNA } \\
\text { gene }(\text { number of copies/ } \boldsymbol{\mu L})\end{array}$ \\
\hline 1 & $95.1 \%$ & -3.446 & 0.993 & $30.42(24.34-38.52)$ & $1.09 \times 10^{4}\left(1.02 \times 10^{1}-2.07 \times 10^{5}\right)$ \\
2 & $91.9 \%$ & -3.531 & 0.996 & $31.02(24.61-37.83)$ & $1.20 \times 10^{5}\left(1.18 \times 10^{1}-3.35 \times 10^{6}\right)$ \\
3 & $93 \%$ & -3.503 & 0.967 & $28.99(24.85-39.07)$ & $1.99 \times 10^{4}\left(1.55 \times 10^{1}-3.85 \times 10^{5}\right)$ \\
4 & $98.1 \%$ & -3.368 & 0.983 & $30.41(20.79-32.86)$ & $2.79 \times 10^{5}\left(1.46 \times 10^{3}-5.62 \times 10^{6}\right)$ \\
5 & $97.5 \%$ & -3.397 & 0.984 & $31.35(25.21-39.82)$ & $7.94 \times 10^{3}\left(1.03 \times 10^{1}-1.90 \times 10^{5}\right)$ \\
\hline
\end{tabular}

(ranging from - to); $\mathrm{r}^{2}$ : correlation coefficient. 
between the quantification of parasitaemia and the occurrence of clinical signs and decreases in productivity indices.

\section{Conclusion}

M. suis has a high rate of occurrence $(76.19 \%)$ in non-technified swine-rearing establishments in Mossoró in the state of Rio Grande do Norte, Brazil.

\section{Acknowledgements}

We are thankful to Fundação de Amparo à Pesquisa do Estado de São Paulo (FAPESP) for Scientific Initiation Fellowship to M. A. Toledo (Process \#2014/00931-7) and financial support to M. R. André (Process \#2015/14896-1), and Fundação para o Desenvolvimento da Unesp (FUNDUNESP) for financial support (Process \#0256/001/14-PROPE/CDC) to M. R. André.

\section{References}

Birkenheuer AJ, Levy MG, Breitschwerdt EB. Development and Evaluation of a Seminested PCR for Detection and Differentiation of Babesia gibsoni (Asian Genotype) and B. canis DNA in Canine Blood Samples. J Clin Microbiol 2003; 41(9): 4172-4177. PMid:12958243. http://dx.doi.org/10.1128/JCM.41.9.4172-4177.2003.

Brasil. Ministério da Agricultura. Epi Info [online]. Brasília: Ministério da Agricultura; 2016 [cited 2016 Oct 05]. Available from: http://www. agricultura.gov.br/animal/especies/suinos

Bustin SA, Benes V, Garson JA, Hellemans J, Huggett J, Kubista $\mathrm{M}$, et al. The MIQE guidelines: minimum information for publication of quantitative real-time PCR experiments. Clin Chem 2009; 55(4): 611622. PMid:19246619. http://dx.doi.org/10.1373/clinchem.2008.112797.

Dietz S, Mack SL, Hoelzle K, Becker K, Jannasch C, Stadler J, et al. Quantitative PCR analysis of Mycoplasma suis shedding patterns during experimental infection. Vet Microbiol 2014; 172(3-4): 581-585. PMid:25037994. http://dx.doi.org/10.1016/j.vetmic.2014.06.019.

Guimarães AMS, Biondo AW, Lara AC, Messick JB. Exploratory study of Mycoplasma suis (Eperythrozoon suis) on four commercial pig farms in southern Brazil. Vet Rec 2007; 160(2): 50-53. PMid:17220522. http:// dx.doi.org/10.1136/vr.160.2.50.
Guimarães AMS, Vieira RFC, Poletto R, Vemulapalli R, Santos AP, Moraes W, et al. A quantitative TaqMan PCR assay for the detection of Mycoplasma suis. J Appl Microbiol 2011; 111(2): 417-425. PMid:21575112. http://dx.doi.org/10.1111/j.1365-2672.2011.05053.x.

Henderson JP, O’Hagan J, Hawe SM, Pratt MC. Anaemia and low viability in piglets infected with Eperythrozoon suis. Vet Rec 1997; 140(6): 144-146. PMid:9050175. http://dx.doi.org/10.1136/vr.140.6.144.

Henry SC. Clinical observations on Eperythrozoonosis. J Am Vet Med Assoc 1979; 174(6): 601-603. PMid:422463.

Hoelzle K, Engels M, Kramer MM, Wittenbrink MM, Dieckmann SM, Hoelzle LE. Occurrence of Mycoplasma suis in wild boars (Sus scrofa L.). Vet Microbiol 2010; 143(2-4): 405-409. PMid:20006452. http://dx.doi. org/10.1016/j.vetmic.2009.11.015.

Hoelzle LE. Haemotrophic mycoplasmas: Recent advances in Mycoplasma suis. Vet Microbiol 2008; 130(3-4): 215-226. PMid:18358641. http:// dx.doi.org/10.1016/j.vetmic.2007.12.023.

Messick JB. Hemotrophic mycoplasmas (hemoplasmas): a review and new insights into pathogenic potential. Vet Clin Pathol 2004; 33(1): 2-13. PMid:15048620. http://dx.doi.org/10.1111/j.1939-165X.2004.tb00342.x.

Mossoró. Prefeitura Municipal. Geografia [online]. Mossoró: Prefeitura Municipal; 2008 [cited 2016 Feb 16]. Available from: http://www. prefeiturademossoro.com.br/mossoro/geografia/

Prullage JB, William RE, Gaafar SM. On the transmissibility of Eperythrozoon suis by Stomoxys calcitrans and Aedes aegypti. Vet Parasitol 1993; 50(1-2): 125-135. PMid:8291187. http://dx.doi.org/10.1016/03044017(93)90013-D

Ritzmann M, Grimm J, Heinritzi K, Hoelzle K, Hoelzle LE. Prevalence of Mycoplasma suis in slaughter pigs, with correlation of PCR results to hematological findings. Vet Microbiol 2009; 133(1-2): 84-91. PMid:18687536. http://dx.doi.org/10.1016/j.vetmic.2008.06.015.

Song Q, Zhang W, Song W, Liu Z, Khan MK, He L, et al. Seroprevalence and risk factors of Mycoplasma suis infection in pig farms in central China. Prev Vet Med 2014; 117(1): 215-221. PMid:25081945. http://dx.doi. org/10.1016/j.prevetmed.2014.07.006

Yuan CL, Liang AB, Yao CB, Yang ZB, Zhu JG, Cui LI, et al. Prevalence of Mycoplasma suis (Eperythrozoon suis) infection in swine and swinefarm workers in Shanghai, China. Am J Vet Res 2009; 70(7): 890-894. PMid:19566474. http://dx.doi.org/10.2460/ajvr.70.7.890.

Zachary JF, Smith AR. Experimental porcine eperythrozoonosis: T-lymphocyte suppression and misdirected immune responses. Am J Vet Res 1985; 46(4): 821-830. PMid:3874572. 